\title{
PENGARUH DISIPLIN KERJA TERHADAP KINERJA KARYAWAN PADA INDUSTRI SAMBEL PECEL WAHYU TUMURUN MADIUN.
}

\author{
Ninik Srijani \\ Dosen Prodi Pendidikan Ekonomi IKIP PGRI Madiun \\ e-mail: ninikikipae@gmail.com
}

Abstract:

This study aims to examine the effect of labor discipline on employee performance. Discipline is one of the factors that affect the performance of employees . Good work discipline of an employee will affect the performance of employees, so the work will be completed effectively and efficiently . The samples in this study using a sample that is saturated all employees sauce Industry pecel WAHYU TUMURUN Madiun as many as 20 people were sampled in this study. Data collection method using a questionnaire with Likert scale to explore the data and performance of employees working Discipline sauce Industry pecel WAHYU TUMURUN Madiun.

Based on the results obtained by the magnitude of the $F$ test results obtained by the value of F is 10.7564 .414 was Ftable Sighitung0 magnitude on the other hand, 004 and Sigprob 0.05 this means that the value of $F \geq F$ table ( $10.756 \geq 4.414)$ or $\leq$ Sighitung Sigprob $(0.004 \leq 0,05)$. In the t-test can be made following the regression line $\mathrm{Y}=8.442+0.741 \mathrm{X}$, meaning that if the increased labor discipline one employee 's performance will increase as much as $0,741 \%$, if other factors remain. The value of $\mathrm{t}$ is 3.280 and $1.734 \mathrm{~T}$ Table, on the other hand the magnitude Sighitung Sigprob 0.004 and 0.05, this means that the value of $t \geq t$ table $(3.280 \geq 1.734)$ or $\leq$ Sighitung Sigprob $(0.004 \leq 0.05)$. On the basis of correlation test, $\mathrm{F}$ test and t-test it can be concluded that there is influence between the Employee Performance Discipline Work on pecel sauce company WAHYU TUMURUN Madiun.

Keyword : Discipline Work, Employee Performance, Human Resources

\section{Pendahuluan}

Untuk mendapatkan SDM yang berkualitas perlu adanya suatu penilaian kinerja suatu karyawan. Hal ini bertujuan untuk mendapatkan karyawan yang berkualitas dan bertanggung jawab, sehingga mampu mencapai suatu tujuan organisasi yang telah direncanakan sebelumnya.

Penilaian kinerja adalah proses yang dilakukan organisasi untuk mengevaluasi atau menilai keberhasilan karyawan dalam melaksanakan tugasnya. Penilaian dapat dilakukan dengan membandingkan hasil kerja yang dicapai karyawan dengan standar pekerjaan. Bila hasil kerja yang diperoleh sampai atau melebihi standar pekerjaan dapat dikatakan kinerja karyawan termasuk pada 
kategori baik. Demikian sebaliknya, seorang karyawan yang hasil pekerjaannya tidak mencapai standar pekerjaan termasuk pada kinerja yang tidak baik atau berkinerja rendah (Wilson Bangun, 2012:231).

Dalam mewujudkan kinerja karyawan menurut Suyadi Prawirosentono (1999:27-31), ada beberapa faktor variabel yang mempengaruhi organisasi dan kinerjanya yaitu antara lain efektivitas dan efisiensi, otoritas dan tanggung jawab, disiplin serta inisiatif. Dengan adanya faktor-faktor tersebut diharapkan perusahaan mampu mewujudkan tujuan yang telah direncanakan secara efektif dan efisien.

Malayu S.P hasibuan (dalam Anwar Prabu, 2000:17-18), mengemukakan bahwa aspek-aspek yang dinilai kinerja yaitu "kesetiaan, hasil kerja, kejujuran, kedisiplinan, kreativitas, kerjasama, kepemimpinan, kepribadian, prakarsa kecakapan dan tanggung jawab".

Salah satu faktor dan aspek yang sangat berpengaruh yaitu kedisiplinan. Dengan diterapkannya sikap disiplin pada karyawan maka akan menciptakan rasa tanggung jawab dan rasa memiliki pada perusahaan tersebut. Hal ini mendorong gairah kerja, semangat kerja dan terwujudnya tujuan perusahaan, karyawan dan masyarakat. Oleh karena itu, setiap manajer selalu berusaha agar para bawahannya mempunyai disiplin yang baik. Seorang manajer dikatakan efektif dalam kepemimpinannya jika para bawahannya berdisiplin baik.

Keberhasilan suatu organisasi dipengaruhi oleh sruktur organisasi yang tepat, pembagian wewenang dan tanggung jawab yang jelas dari para peserta atau aktor yang berkecimpung dalam organisasi tersebut. Tanggung jawab akan tugasnya atau rasa tanggung jawab berkaitan atau dapat dikaitkan dengan tingkat disiplin para peserta organisasi. Semakin baik disiplin para peserta organisasi, diharapkan kinerja organisasi dalam mencapai tujuan akan bertambah baik (Suyadi Prawirosentono, 1999:32).

Untuk dapat bertahan dan bersaing sampai saat ini tentunya tidak lepas dari peran karyawan. Peneliti ingin mengetahui seberapa jauh disiplin karyawan yang terwujud dalam kinerjanya. Dengan melihat dari sisi disiplin kerja paling tidak akan mencerminkan kinerja karyawannya.

Dengan adanya disiplin antara lain dapat mempengaruhi kinerja dan produktivitas. Salah satu yang sangat berpengaruh yaitu pada kinerja karyawan. Karena dengan adanya disiplin dapat mewujudkan kinerja yang mampu mancapai sasaran tujuan, visi dan misi industry sambel pecel tersebut untuk mampu bersaing dan terus berkembang.

Dalam hal ini, untuk melakukan proses itu semua memerlukan sumber daya manusia yang baik dan berkualitas. Dalam mewujudkannya tidak terlepas dari peran karyawan. Kinerja karyawan sangat diperlukan untuk menentukan keberhasilan dari tujuan sebuah organisasi. Salah satu hal yang dapat mendukung terwujudnya kinerja karyawan yaitu didukung adanya disiplin karyawan yang tinggi serta didukung oleh faktor-faktor lain yang saling berkaitan. Dengan adanya disiplin dari para karyawan, maka karyawan tersebut mempunyai kinerja yang baik pula sehingga dapat mencapai tujuan perusahaan secara efektif dan efisien. 


\section{Metodologi Penelitian}

Penelitian ini dilaksanakan di industry sambel pecel "WAHYU TUMURUN" Madiun. Dengan alamat Jalan Timbangan No 19 Desa Banjarejo, kecamatan Taman Kota Madiun dengan alasan: 1) belum pernah ada penelitian tentang disiplin kerja terhadap kinerja karyawan di industry sambel pecel "WAHYU TUMURUN" Madiun. 2) Merupakan industry sambel pecel yang bertahan pengelolaaanya ditengah persaingan yang sangat ketat. 3) Tersedianya data-data yang diperlukan dalam penelitian. Desain dalam Penelitian ini adalah desain penelitian deskriptif. Menurut Husein Umar (2011:34), desain deskriptif bertujuan untuk menguraikan sifat atau karakteristik dari suatu fenomena tertentu. Jadi dalam riset dengan desain ini jangan melakukan kesimpulan yang terlalu jauh atas data yang ada, karena tujuan dari desain ini hanya mengumpulkan fakta dan menguraikannya secara menyeluruh dan teliti sesuai dengan persoalan yang akan dipecahkan. Variabel independen atau variabel bebas (X), dalam penelitian ini variabel independen atau bebasnya $(\mathrm{X})$ adalah disiplin kerja. Variabel dependen atau variabel terikat (Y), yaitu kinerja karyawan.

Dalam penelitian ini yang menjadi sampel dalam penelitian ini adalah semua karyawan Industri sambel pecel WAHYU TUMURUN Madiun sebanyak 20 karyawan. Metode Pengumpulan data dengan menggunakan teknik angket dengan menggunakan skala likert. Jumlah soal yang dibagi dalam 2 variabel, dengan perincian untuk variabel Disiplin kerja 10 soal dan variabel Kinerja karyawan 10 soal.

\section{Hasil Penelitian}

Variabel Disiplin Kerja

Deskripsi dari variabel disiplin kerja, dengan jumlah data $(\mathrm{N})$ sebanyak 20 karyawan mempunyai deskripsi data sebagai berikut : (a) jumlah skor total sebesar 817; (b) nilai rata-rata hitung (mean) sebesar 40,85; (c) median sebesar 41,50; (d) modus sebesar 38; (e) standar deviasi sebesar 4,648; (f) nilai minimum sebesar 30; (g) nilai maximum sebesar 48.

Dari hasil analisis deskriptif disiplin kerja di atas dapat diketahui hasil analisis kuesioner dari 20 karyawan yang berada di atas nilai rata-rata $\geq 40,85$ sebanyak 12 karyawan atau $60 \%$. Sedangkan yang berada di bawah nilai rata-rata sebanyak 8 karyawan atau 40\%. Hal ini dapat disimpulkan kedisiplinan kerja industry sambel pecel WAHYU TUMURUN Madiun adalah baik, karena 12 karyawan atau $60 \%$ berada di atas nilai rata-rata.

\section{Variabel Kinerja Karyawan}

Deskripsi dari variabel kinerja karyawan, dengan jumlah data $(\mathrm{N})$ sebanyak 20 karyawan mempunyai deskripsi data sebagai berikut : (a) Nilai total skor sebesar 774; (b) Nilai mean sebesar 38,70; (c) Nilai median sebesar 40,00; (d) Nilai modus sebesar 40; (e) Standar deviasi sebesar 5,630; (f) Nilai minimum sebesar 24; (g) Nilai maksimum sebesar 44.

Dari hasil analisis deskriptif kinerja karyawan di atas dapat diketahui hasil analisis kuesioner yang memperoleh nilai di atas rata-rata $\geq 38,70$ sebanyak 14 karyawan atau 70\%. Sedangkan yang berada dibawah nilai rata-rata sebanyak 6 
karyawan atau 30\%. Hal ini dapat disimpulkan kedisiplinan kerja industry sambel pecel WAHYU TUMURUN Madiun adalah baik, karena 12 karyawan atau 70\% berada di atas nilai rata-rata.

\section{Hasil Pengujian Hipotesis}

Hasil Uji Validitas menunjukan bahwa semua item soal dalam angket tersebut valid. Item soal dalam angket dinyatakan valid karena nilai $r_{x y}$ lebih besar dari nilai $r_{\text {tabel }}$ pada taraf signifikasi 0,05 yaitu 0.444 . Oleh karena itu semua item soal untuk instrumen variabel kedisiplinan kerja dan instrumen variabel Kinerja karyawan dapat dipercaya.

Hasil Uji Reliabilitas Kedisiplinan Kerja dan Kinerja Karyawan. Uji reliablitas dilakukan dengan rumus Cronbach's Alpha. Dalam uji reliabilitas tersebut yang dilihat bukan nilai koefisien reliabilitasnya akan tetapi nilai reliabiltasnya nilai Crobach's Alphanya.

Data dari penelitian di dapat hasil uji reliabilitas terhadap angket kedisiplinan kerja dan kinerja karyawan diperoleh nilai Cronbah's Alpha masingmasing sebesar 0,792 dan 0,837. Karena nilai Cronbach's Alpha terdiri dari 0,7 dan 0,8 dapat disimpulkan bahwa data yang dikumpulkan melalui angket kedisiplinan kerja dan kinerja karyawan dapat diterima dan reliabel (dipercaya). Oleh karena itu angket kedisiplinan kerja dan kinerja karyawan dapat digunakan sebagai alat pengumpul data dalam penelitian

Pengujian hipotesis dalam penelitian adalah pengujian untuk mencari hubungan sekaligus pengaruh antara variabel kedisiplinan kerja dan variabel kinerja karyawan.

\section{Uji F/Uji Fisher/Uji Keseluruhan}

Uji Fisher dilakukan untuk mengetahui pengaruh antara kedisiplinan kerja terhadap kinerja karyawan.

Hasil uji di peroleh bahwa nilai Sig $_{\text {hit }}$ sebesar 0,004 dan nilai $\operatorname{Sig}_{\text {prob }}$ besarnya 0,05 . Dilain pihak diketahui nilai $\mathrm{F}_{\text {hitung }}$ sebesar 10,756 sedangkan nilai $\mathrm{F}_{\text {tabel }}$ sebesar 4,414. Hal ini berarti bahwa $\mathrm{Sig}_{\text {hit }} \leq \mathrm{Sig}_{\text {prob }}$ $(0,004 \leq 0,05)$ atau $F_{\text {hit }} \geq F_{\text {tab }}(10,756 \geq 4,414)$. Dengan demikian $H_{0}$ ditolak, artinya kedisiplinan kerja memiliki pengaruh terhadap kinerja karyawan pada pada industry sambel pecel WAHYU TUMURUN Madiun.

Selain digunakan untuk mencari pengaruh uji Fisher atau Anova ini digunakan untuk menguji linearitas. Berarti ada hubungan yang linier antara variabel kedisiplinan kerja dengan kinerja karyawan

\section{Uji t/Uji Beda Pengaruh/Uji Koefisien Regresi}

Uji t digunakan untuk mencari beda pengaruh antara kedisiplinan kerja terhadap kinerja karyawan.

Atas dasar data yang diolah diperoleh persamaan garis regresi sebagai berikut: $\mathrm{Y}=8,442+0,741 \mathrm{X}$, artinya adalah apabila kedisiplinan kerja ditingkatkan satu kali akan terjadi kenaikan kinerja karyawan sebanyak $1 \%$, kinerja akan meningkat pula sebesar $0,741 \%$, sedangkan faktor yang lainnya tetap. 
Selanjutnya diketahui bahwa nilai Sighit adalah 0,004 sedangkan $\mathrm{Sig}_{\text {prob }}$ 0,05. Dilain pihak nilai $\mathrm{t}_{\text {hitung }}$ adalah 3,280 sedangkan $\mathrm{t}_{\text {tabel }}$ sebesar 1,734. Hal ini berarti bahwa nilai $\operatorname{Sig}_{\text {hit }} \leq \operatorname{Sig}_{\text {prob }}(0,004 \leq 0,05)$ atau $t_{\text {hit }} \geq t_{\text {tab }}$ $(3,280 \geq 1,734)$. Atas dasar uji t tersebut dapat disimpulkan tolak $\mathrm{H}_{0}$, artinya ada beda pengaruh kedisiplinan kerja terhadap kinerja karyawan pada industry sambel pecel WAHYU TUMURUN Madiun

Dari hasil analisis data yang telah dilakukan untuk uji Fisher diperoleh bahwa nilai $\mathrm{Sig}_{\text {hit }}$ sebesar 0,004 dan nilai $\mathrm{Sig}_{\text {prob }}$ besarnya 0,05. Dilain pihak diketahui nilai $F_{\text {hitung }}$ sebesar 10,756 sedangkan nilai $F_{\text {tabel }}$ sebesar 4,414. Hal ini berarti bahwa $\operatorname{Sig}_{\text {hit }} \leq \operatorname{Sig}_{\text {prob }}(0,004 \leq 0,05)$ atau $F_{\text {hit }} \geq$ $F_{\text {tab }}(10,756 \geq 4,414)$. Dapat disimpulkan bahwa $H_{0}$ ditolak, artinya keisiplinan kerja memiliki pengaruh terhadap kinerja karyawan pada industry sambel pecel WAHYU TUMURUN Madiun.

Dari hasil analisis yang digunakan dalam uji t diperoleh persamaan regresi sebagai berikut: $\mathrm{Y}=8,442+0,741 \mathrm{X}$. Dapat disimpulkan dari persamaan tersebut adalah apabila kedisiplinan kerja naik atau ditingkatkan sebesar $1 \%$, maka kinerja karyawan akan naik pula sebanyak $0,741 \%$, sedangkan faktor lain dianggap tetap.

Selain diperoleh persamaan regresi diperoleh nilai $\mathrm{Sig}_{\text {hit }}$ sebesar 0,004 dan nilai $\mathrm{Sig}_{\text {prob }}$ besarnya 0,05. Dilain pihak nilai $\mathrm{t}_{\text {hitung }}$ adalah 3,280 sedangkan nilai $\mathrm{t}_{\text {tabel }}$ sebesar 1,734 . Hal ini berarti bahwa $\operatorname{Sig}_{\text {hit }} \leq \operatorname{Sig}_{\text {prob }}$ $(0,004 \leq 0,05)$ atau $t_{\text {hit }} \geq t_{\text {tab }}(3,280 \geq 1,734)$. Dapat disimpulkan bahwa $\mathrm{H}_{0}$ ditolak, artinya kedisiplinan kerja memiliki beda pengaruh terhadap kinerja karyawan pada industry sambel pecel WAHYU TUMURUN Madiun.

\section{Pembahasan}

Hasil penelitian menunjukan bahwa kedisiplinan kerja mempunyai pengaruh terhadap kinerja karyawan. Hal ini menunjukan bahwa dengan keadaan kedisiplinan kerja yang baik untuk mematuhi peraturan sehingga dapat meningkatkan kinerja karyawan. Karena kinerja karyawan merupakan jumlah yang dihasilkan dan jumlah setiap sumber yang dipergunakan selama produksi berlangsung.

Pembahasan untuk penelitian ini menggunakan uji regresi (uji Fisher, dan uji t) pembahasan untuk uji tersebut adalah sebagai berikut:

\section{Pembahasan Uji Fisher}

Untuk uji Fisher diperoleh nilai Sig $_{\text {hit }}$ sebesar 0,004 dan nilai Sig $_{\text {prob }}$ sebesar 0,05 , dilain pihak diketahui nilai $F_{\text {hitung }}$ sebesar 10,756 sedangkan nilai $\mathrm{F}_{\text {tabel }}$ sebesar 4,414. Hal ini berarti bahwa $\operatorname{Sig}_{\text {hit }} \leq \operatorname{Sig}_{\text {prob }}$ $(0,004 \leq 0,05)$ atau $F_{\text {hit }} \geq F_{\text {tab }}(10,756 \geq 4,414)$. Dengan hal ini berarti $\mathrm{H}_{0}$ ditolak, artinya ada pengaruh kedisiplinan kerja terhadap kinerja karyawan pada industry sambel pecel WAHYU TUMURUN Madiun.

\section{Pembahasan Uji t}

Dapat dilihat persamaan regresi yaitu $\mathrm{Y}=8,442+0,741 \mathrm{X}$ sedangkan untuk uji $\mathrm{t}$ diperoleh nilai uji t diperoleh nilai $\mathrm{Sig}_{\text {hit }}$ sebesar 0,004 dan nilai $\mathrm{Sig}_{\text {prob }}$ 0,05, dilain pihak nilai $t_{\text {hitung }}$ adalah 3,280 sedangkan nilai $\mathrm{t}_{\text {tabel }}$ sebesar 1,734. Hal ini berarti bahwa $\mathrm{Sig}_{\text {hit }} \leq \mathrm{Sig}_{\text {prob }}$ $(0,004 \leq 0,05)$ atau $t_{\text {hit }} \geq \mathrm{t}_{\text {tab }}(3,280 \geq 1,734)$. Hal ini $\mathrm{H}_{0}$ ditolak, artinya 
ada beda pengaruh kedisiplinan kerja terhadap kinerja karyawan pada industry sambel pecel WAHYU TUMURUN Madiun.

Kedisiplinan menunjukan suatu kondisi yang ada pada diri karyawan dalam ketaatan terhadap peraturan dan ketetapan home industri. Oleh karena itu, kinerja karyawan dalam suatu organisasi sangat dipengaruhi oleh kedisiplinan kerja. Hal tersebut kedisiplinan kerja dikemukakan oleh Pandji Anoraga (2007: 240) bahwa disiplin kerja adalah "sikap kejiwaan seseorang atau kelompok yang senantiasa berkehendak untuk mengikuti atau mematuhi segala peraturan yang telah ditentukan".

Dari hasil penelitian menunjukkan bahwa Disiplin kerja mempunyai hubungan sekaligus pengaruh terhadap kinerja. Artinya apabila diterapkan disiplin dalam pabrik tersebut dapat menciptakan kinerja karyawan yang baik. Dengan adanya disiplin yang baik, karyawan akan bertanggung jawab pada pekerjaannya dan dapat terselesaikan secara efektif dan efisien.

Disiplin yang baik mencerminkan besarnya rasa tanggung jawab seseorang terhadap tugas-tugas yang diberikan kepadanya. Hal ini mendorong gairah kerja, semangat kerja dan terwujudnya tujuan perusahaan, karyawan dan masyarakat. Oleh karena itu, setiap manajer selalu berusaha agar para bawahannya mempunyai disiplin yang baik. Seorang manajer dikatakan efektif dalam kepemimpinannya jika para bawahannya berdisiplin baik (Malayu S.P. Hasibuan, 2000:190).

Jadi, kedisiplinan adalah fungsi MSDM yang terpenting dan menjadi tolok ukur untuk mengukur/mengetahui apakah fungsi-fungsi MSDM lainnya secara keseluruhan telah dilaksanakan dengan baik atau tidak. Kedisiplinan karyawan yang baik, mencerminkan bahwa fungsifungsi MSDM lainnya telah dilaksanakan sesuai dengan rencana. Sebaliknya jika kedisiplinan karyawan kurang baik, berarti penerapan fungsi-fungsi MSDM pada perusahaan kurang baik (Malayu S.P Hasibuan, 2000:195) .

\section{Penutup}

Simpulan

Berdasarkan hasil analisis data dan pembahasan pada bab sebelumnya dapat disimpulkan Disiplin kerja yang dilaksanakan pada industry sambel pecel WAHYU TUMURUN Madiun cukup efektif dan efisien. Hal ini dapat dilihat dari tingkat kedisiplinan yang cukup tinggi. Berdasarkan hasil penelitian yang telah dilakukan disiplin kerja dengan jumlah data $(\mathrm{N})$ sebanyak 20 karyawan mempunyai deskripsi data sebagai berikut : (a) jumlah skor total sebesar 817; (b) nilai rata-rata hitung (mean) sebesar 40,85; (c) median sebesar 41,50; (d) modus sebesar 38; (e) standar deviasi sebesar 4,648; (f) nilai minimum sebesar 30; (g) nilai maximum sebesar 48. 
Kinerja karyawan merupakan suatu hasil kerja baik secara kualitas maupun kuantitas dalam suatu organisasi atau perusahaan. Kinerja karyawan dipengaruhi oleh beberapa faktor salah satunya yaitu disiplin kerja. Dengan diterapkannya sikap disiplin yang baik, kinerja karyawan juga berjalan dengan baik dan memperoleh hasil yang maksimal sesuai dengan rencara atau tujuan awal dari perusahaan. Dari data penelitian (N) sebanyak 20 karyawan mempunyai deskripsi data sebagai berikut : (a) Nilai total skor sebesar 774; (b) Nilai mean sebesar 38,70; (c) Nilai median sebesar 40,00; (d) Nilai modus sebesar 40; (e) Standar deviasi sebesar 5,630; (f) Nilai minimum sebesar 24; (g) Nilai maksimum sebesar 44.

Disiplin Kerja mempunyai pengaruh terhadap kinerja karyawan pada industry sambel pecel WAHYU TUMURUN Madiun. Y = 8,442 + 0,741X. Dapat disimpulkan dari persamaan tersebut adalah apabila kedisiplinan kerja naik atau ditingkatkan sebesar $1 \%$, maka kinerja karyawan akan naik pula sebanyak 0,741\%, sedangkan faktor lain dianggap tetap. Dari Hasil Uji F nilai $F_{\text {hitung }}$ sebesar 10,756 sedangkan nilai $F_{\text {tabel }}$ sebesar 4,414. Hal ini berarti bahwa $\operatorname{Sig}_{\text {hit }} \leq \operatorname{Sig}_{\text {prob }}(0,004 \leq 0,05)$ atau $F_{\text {hit }} \geq F_{\text {tab }}(10,756 \geq 4,414)$, artinya apabila disiplin kerja ditingkatkan satu kali akan terjadi kenaikan kinerja karyawan sebanyak. Selain diperoleh persamaan regresi diperoleh nilai $\mathrm{Sig}_{\text {hit }}$ sebesar 0,004 dan nilai $\mathrm{Sig}_{\text {prob }}$ besarnya 0,05. Dilain pihak nilai $\mathrm{t}_{\text {hitung }}$ adalah 3,280 sedangkan nilai $t_{\text {tabel }}$ sebesar 1,734. Hal ini berarti bahwa $\operatorname{Sig}_{\text {hit }} \leq \operatorname{Sig}_{\text {prob }}(0,004$ $\leq 0,05)$ atau $t_{\text {hit }} \geq t_{\text {tab }}(3,280 \geq 1,734)$. Dapat disimpulkan bahwa $\mathrm{H}_{0}$ ditolak, artinya kedisiplinan kerja memiliki beda pengaruh terhadap kinerja karyawan pada industry sambel pecel WAHYU TUMURUN Madiun.

\section{Saran}

\section{Bagi Karyawan}

Sesuai dengan hasil penelitian yang telah dilakukan. Terbukti bahwa disiplin memberikan pengaruh terhadap kinerja karyawan, maka karyawan diharapkan mampu meningkatkan kedisiplinannya dalam bekerja. Sehingga dapat mencapai tujuan perusahaan dan bertanggung jawab terhadap tugas yang telah diberikan.

\section{Bagi Industry sambel pecel WAHYU TUMURUN}

Berdasarkan penelitian yang telah di lakukan di industry sambel pecel WAHYU TUMURUN. Bahwa disiplin mempunyai pengaruh yang cukup besar, diharapkan dalam mengelola pabrik lebih meningkatkan lagi kedisiplinan. Peningkatan disiplin bisa melalui pemberian sanksi yang tegas, pemberian motivasi, pemberian hadiah maupun dengan cara yang lainnya. Seorang atasan juga harus bijak dalam menyikapi suatu sanksi ataupun pelanggaran yang telah dilakukan oleh seorang karyawan. Dengan begitu diharapkan tercipta kerjasama dan kedisiplinan yang baik.

\section{Bagi Peneliti selanjutnya}

Peneliti diharapkan mampu mengembangkan penelitian yang telah ada, serta mencari faktor-faktor lain yang mempunyai pengaruh bagi kinerja karyawan. Sehingga dengan adanya pengembangan penelitian dapat mengetahui cara 
peningkatan kinerja, baik secara kualitas maupun kuantitas dalam perusahaan ataupun organisasi.

\section{DAFTAR PUSTAKA}

Achmad S. Ruky. 2001. Manajemen Penggajian \& Pengupahan untuk Karyawan Perusahaan. Jakarta: PT Gramedia Pustaka Utama.

Achmad Zanbar Soleh. 2005. Ilmu Statistik Pendekatan Teori dan Aplikatif disertai Contoh Penggunakan SPSS. Bandung: Rekayasa Sains.

Algifari. 2003. Statistik Induktif. Yogyakarta: Akademi Perusahaan YKPN.

DIKNAS. 2005. Ilmu Pengetahuan Sosial - Ekonomi. Jakarta: Dinas Pendidikan Nasional.

Duwi Priyatno. 2010. Teknik Mudah Dan Cepat Melakukan Analisis Data Penelitian. Yogyakarta: Gava Media.

Edy Sutrisno. 2009. Manajemen Sumber Daya Manusia. Jakarta: Prenada Media Group

Gabriel Amin Silalahi. 2003. Metodologi Penelitian dan Studi Kasus. Sidoarjo: CV Citra Media.

Hani Handoko.2011. Manajemen Personalia Dan Sumber Daya Manusia. Yogyakarta: BPFE-Yogyakarta.

Husaini Usman dan Purnomo Setiady Akbar. 2004. Metodologi Penelitian Sosial. Jakarta: PT Bumi Aksara.

Husein Umar. 2011. Metode Penelitian untuk Skripsi Dan Tesis Bisnis edisi kedua. Jakarta: PT RajaGrafindo Persada.

Juliansyah Noor. 2011. Metode Penelitian Sripsi, Tesis, Disertasi, dan Karya Ilmiah. Jakarta: Prenada Media. 
Lijan Poltak Sinambela. 2012. Kinerja Pegawai Teori Pengukuran dan Implikasi. Yogyakarta: Graha Ilmu.

Moehar Daniel. 2003. Metode Penelitian Sosial Ekonomi. Jakarta: PT Bumi Aksara.

Muchdarsyah Sinungan. 2005. Produktivitas Apa dan Bagaimana. Jakarta: PT Bumi Aksara.

Nanang Martono. 2010. Metode Penelitian Kuantitatif Analisis Isi dan Analisis Data Sekunder. Jakarta: PT RajaGrafindo Persada.

Nasution. 2004. Metode Research: penelitian Ilmiah. Jakarta: PT Bumi Aksara.

Pandji Anoraga. 2007. Pengantar Bisnis Pengelolaan Bisnis Dalam Era Globalisasi. Jakarta: PT Rineka Cipta.

Sedarmayanti. 2009. Tata Kerja dan Produktivitas Kerja Suatu Tinjauan Dari Aspek Ergonomi Atau Kaitan Antara Manusia Dengan Lingkungan Kerjanya. Badung: CV. Mandar Maju.

Sedarmayanti. 2011. Membangun dan Mengembangkan Kepemimpinan serta Meningkatkan Kinerja untuk Meraih Keberhasilan. Badung: PT. Refika Aditama.

Siswanto Sastrohadiwiryo. 2005. Manajemen Tenaga Kerja Indonesia Pendekatan Administratif dan Operasional. Jakarta: PT Bumi Aksara.

Sondang P. Siagian. 2000. Manajemen Sumber Daya Manusia. Jakarta: Bumi Aksara

Sugiyono. 2007. Metodologi Penelitian Kuantitatif Kualitatifdan $R \& D$. Bandung: Alfabeta.

Suharsimi Arikunto. 2010. Prosedur Penelitian Suatu Pendekatan Prektik. Jakarta: Rineka Cipta. 
Tim IKIP PGRI MADIUN. 2013. Pedoman Penulisan Skripsi edisi 2013. Madiun: IKIP PGRI MADIUN.

Usman Rianse dan Abdi. 2012. Metodologi Penelitian Sosial dan Ekonomi Teori dan Aplikasi. Bandung: Alfabeta.

Veithzal Rivai. 2005. Manajemen Sumber Daya Manusia untuk Perusahaan. Jakarta: PT RajaGrafindo Persada.

Veithzal Rivai. 2009. Manajemen Sumber Daya Manusia untuk Perusahaan. Jakarta: PT RajaGrafindo Persada.

Wibowo. 2007. Manajemen Kinerja. Jakarta: PT RajaGrafindo Persada. 